\title{
'i want to go to school but ...' The case of the Penan and Orang Asli Children of Malaysia
}

\author{
Ong Puay Liu ${ }^{1}$, Ong Puay Tee ${ }^{2}, \mathrm{Ng} \mathrm{Kum} \mathrm{Loy}{ }^{3}$, Ong Puay Hoon ${ }^{4}$ \\ \{ puayliu@gmail.com¹, ptong@mmu.edu.my², ngkumloy@yahoo.com ${ }^{3}$, ongpuayhoon@ntu.edu.sg \} \\ Institute of Ethnic Studies, Universiti Kebangsaan Malaysia, \\ Bangi, Selangor, Malaysia ${ }^{1}$, Multimedia University, Melaka Campus, Malaysia ${ }^{2}$, Dyslexia \\ Association of Sarawak, Kuching, Sarawak, Malaysia ${ }^{3,4}$
}

\begin{abstract}
This paper argues that one of the main contributory factors is 'dysteachia', a term coined to refer to the inappropriate methodology used by teachers in schools to teach language, in particular, Malay and English languages. Primary schools in Malaysia have the tendency to use the whole word approach to teach reading and writing in English, and the syllabic approach (letter-name) for the Malay language (Bahasa Melayu). Students with reading difficulties have problems with these approaches. Through its experience of teaching students with reading difficulties, the Dyslexia Association of Sarawak (DASwk) have created a phonics-based program with special features: it is structured, cumulative, multi-sensorial and utilises an array of tools and activities to stimulate interest, attention as well as cultivate appropriate skills progressively. For the English language program, it is called SMARTER*phonics and the Malay program is called foniks*PINTAR. The application of these two programs through one-week literacy camps, showed that SMARTER*phonics and foniks*PINTAR have proven to be effective learning strategies to enhance the reading skills of Penan and Orang Asli Temuan children who participated in these programs. In addition, these phonics-based programs also serve as advocacy tools to inspire these children to want to go to school, to remain in school and to acquire an education through the confidence they have acquired through their ability to read and write.
\end{abstract}

Keywords: Sustainable Development Goal (SDG), Penan and Orang Asli Children

\section{Introduction}

The indigenous peoples (Orang Asli and Orang Asal) of Malaysia have historically been associated with isolation and remoteness due to their preferred habitations along rivers, in jungles, mountains and valleys and life-styles as hunters and food-gatherers. As of 2015, the indigenous peoples of Malaysia were estimated to account for $13.9 \%$ of the 31 million total population (Lasimbang 2016). The Orang Asli are the indigenous minority peoples of Peninsular Malaysia. The 18 Orang Asli subgroups within the Negrito (Semang), Senoi and Aboriginal-Malay account for 205,000 persons, representing a mere $0.84 \%$ of the national population.

Ever since the five-year Malaysia Plans were published, the Penan community of Sarawak and the Orang Asli community of Peninsular Malaysia have never failed to be listed among the most impoverished of Malaysians until today (Nicholas 2000). 
In the case of the Orang Asli, it was found that an average 94.4\% of Orang Asli schoolchildren who registered in Primary One never reached the end of secondary schooling 11 years later (Hasan 1997). According to Hasan's analysis, an average of $62.1 \%$ of Orang Asli students dropped out annually for the period 1971-1995, and 39.2\% (almost 4 in 10 young children) did not go to school at all (Hasan 1997).

In 2011, the Human Rights Commission of Malaysia (SUHAKAM) published a report titled 'Laporan Status Hak Pendidikan Kanak-Kanak Orang Asli" (Report on the Status of the Right to Education among Orang Asli Children). In this report, SUHAKAM noted that through its research, it was found that in several areas, Orang Asli children did not attend school at all. In addition many Orang Asli children have stopped schooling. Among the factors contributing to this dismal state of education and schooling among Orang Asli children were problem of transportation to school, lack of formal documentation such as birth certificates and identity cards, attitudes of Orang Asli parents and children towards education and schooling, attitudes of school Heads, Principals and teachers, teaching and learning pedagogy, lack of teaching equipment and learning aids, shortcomings in the implementation of the Supplementary Food Plan (Rancangan Makanan Tambahan, RMT) and Poor Student Trust Fund (Kumpulan Wang Amanah Pelajar Miskin, KWAPM) (SUHAKAM 2011: i).

According to the Education Blueprint 2013-2025 published by the Ministry of Education, several economic, geographic, and cultural factors limit Orang Asli students' access to quality education. Firstly, higher incidences of poverty and the tendency to live in remote locations means that many Orang Asli students do not attend preschool and thus start from a low literacy and numeracy base in Year 1. Additionally, Bahasa Malaysia is not the mother tongue for most of these students, which further impedes learning. Secondly, principals and teachers report that existing training programmes do not sufficiently prepare them for the complexities of working with these communities. They struggle to support students on multiple levels: from helping them integrate with their non-Orang Asli peers, to convincing them and their families of the value of pursuing basic and further education (Ministry of Education 2013: 4-21).

In the case of the Penan community currently residing in relocated areas in Murum, Sarawak, accessibility to formal education is still limited. The Penans recognised the value and importance of formal education for the advancement and well-being of the community. Nevertheless, their aspiration for formal education is constrained by the fact that schools are often not located in the vicinity of their villages.

\section{Literature Review}

\subsection{Education among Penan and Orang Asli Communities}

The Sustainable Development Goals (SDGs), also called Global Goals from Transforming Our World: the 2030 Agenda for Sustainable Development, are committed to achieving sustainable development where 'no one is to be left behind'. The 17 SDGs represent a universal call of action to end poverty, protect the planet and ensure that all people enjoy peace and prosperity. As quality education is the main foundation in achieving progress in each dimension, SDG Goal Number 4 seeks to ensure inclusive and equitable quality education and promote lifelong learning opportunities for all by 2030 (United Nations 2015).

The importance of the right to education epitomises the indivisibility and interdependence of all human rights (UNESCO 2014; Ong et al. 2016) and is supported by the Universal Declaration of Human Rights (1948) and the Convention on the Rights of the Child (1989), 
that all children, young people and adults have the human right to benefit from an education that will meet their basic learning needs in the best and fullest sense of the term. It is an education geared towards tapping each individual's talents and potential, and developing learners' personalities, so that they can improve their lives and transform their societies (UNESCO 2000: 8). Illiterate persons have lower or minimal opportunities for gainful employment and increased risk of poverty, involvement in delinquency, criminal activities and incarceration (see for example, Hogenson 1974; Adiseshiah 1990; Brunner 1993; Nordtveit 2008).

In its Education Blueprint 2013-2025, the Ministry of Education Malaysia maintains that every Malaysian child deserves equal access to an education that will enable that child to achieve his or her potential (Ministry of Education 2013: E-9; Ong et al. 2016). Although 97.3\% of Malaysia's population aged 10-64 are literate in 2010 (Department of Statistics Malaysia 2013: 3), there are grossly different literacy rates among its diverse communities, especially between indigenous and non-indigenous communities. Indigenous and other minority groups comprise groups such as Orang Asli, Penan, Peribumi Sabah and Peribumi Sarawak. They account for $4 \%$ of all Malaysian primary and secondary school students. $68 \%$ of these students live in rural areas, and $80 \%$ in the states of Sabah and Sarawak. The Blueprint reported that statistics on student outcomes of indigenous and other minority groups in National schools apart from those regarding Orang Asli students is limited. Thus, while acknowledging that some difference in experience is likely to exist between groups, it noted that the Orang Asli experience will be used as a gauge for how indigenous and other minority groups are faring, at least until better data is available (Ministry of Education 2013: 4-20).

Of particular interest is that children of Orang Asli in Peninsular Malaysia and the Penan community of Sarawak have been identified in the Education Blueprint as communities requiring special attention in its aspiration to achieve equitable education for all (Ministry of Education 2013: 4-20-21). Literacy levels among the children of these communities (as per note above, statistics available only for Orang Asli children) are lowest when compared to other communities and notwithstanding, high rates of absenteeism from school, dropouts and poor performances in examinations (Center for Orang Asli Concerns 2012).

The Ministry's current policy is to provide Orang Asli and Penan students with educational opportunities relevant to their needs. As such, in July 2012, the Ministry launched a dedicated 5-year transformation plan for Orang Asli education that ran from 2013 to 2018. A comparable plan for the minority groups in Sabah and Sarawak was launched in April 2013 (Ministry of Education 2013: 4-21). However, to date, as noted by the Education Blueprint, statistics regarding student outcomes of indigenous and other minority groups in National schools apart from those regarding Orang Asli students is limited.

\subsection{Towards A More Effective Reading Methodology}

In response to the need for more effective methods of teaching reading and writing to young children, the Dyslexia Association of Sarawak (DASwk), which is based in Kuching in Sarawak, Malaysia proposed an alternative paradigm to help children increase their literacy skills with the hope of enhancing their opportunities for social inclusion in future. Primary schools in Malaysia use whole word approach to teach reading and writing in English and syllabic method (using letter names) to teach for Bahasa Malaysia. Not all children are able to learn to read and write with these two instructional techniques. From its years of experiences of teaching struggling readers, DASwk has developed an innovative, highly structured, cumulative and multi-sensorial reading programme which uses letter sounds (Ong et al. 2014). This program, called SMARTER*phonics ${ }^{\mathrm{TM}}$ (and foniks*PINTAR, its counterpart for Bahasa 
Melayu), has helped struggling \& poor readers and children in rural and remote schools in Sarawak since 2009. The phonics approach has been widely documented to be an effective instructional technique for reading and writing (Fountas \& Pinnel, 1999; National Reading Panel 2000).

Since 2011, DASwk has conducted SMARTER*phonics ${ }^{\mathrm{TM}}$ workshops for teachers in preschools, schools and teacher training colleges as well as camps for school-going children, particularly children in LINUS (Literacy and Numeracy Screening) remedial classes in the various administrative divisions of Sarawak. The modus operandi of having the camp as a one-week stay-in style is to provide an intensive and immersive environment for the children to learn. Such camps had also been conducted for children in rural and remote schools, and children of the marginalized indigenous Penan community in Sarawak.

The "Literacy for Social Inclusion - the Right to Read for All Children Program", was introduced in Peninsular Malaysia in 2016 for the first time among Orang Asli communities residing in the State of Selangor, Peninsular Malaysia. This program aims to ensure that all participating children will have the basic decoding and encoding skills to read and write in English. Hence, at the end of the one-week program, participating children will be able to (i) read and write in English up to their age-appropriate level; and (ii) read and write in English up to their age-appropriate level.

In 2016-2017, DASwk, its collaborators and funders conducted a once-a-month literacy program on Sundays in Bahasa Melayu (BM) and English among Orang Asli Temuan children in their own villages at Kampung Kachau Luar, Ulu Semenyih and Kampung Gabai, Dusun Tua. Both villages are in the state of Selangor. Poor and erratic attendance of these children impacted its learning outcomes. The participants were either working, looking after their younger siblings or looking for food or things to sell from the surrounding jungles. In 2018, the team organized two one-week literacy camps for Bahasa Melayu held at a venue outside the Orang Asli children's village to ensure full and continuous attendance. These camps, conducted in stay-in and away-from-home format, aimed to provide an intensive and immersive environment for the mastery of reading and writing in BM among the targeted children and youths.

In 2018 too, two one-week camps were organized for the Penan children residing at Tegulang and Metalun, Murum, Sarawak.

The next section will provide a brief description of the Orang Asli and Penan communities.

\subsection{Orang Asli of Selangor}

The Orang Asli subgroup selected for this literacy program is the Temuan community. The Temuans belong to the Proto Malay category, as illustrated in the snapshot below: 


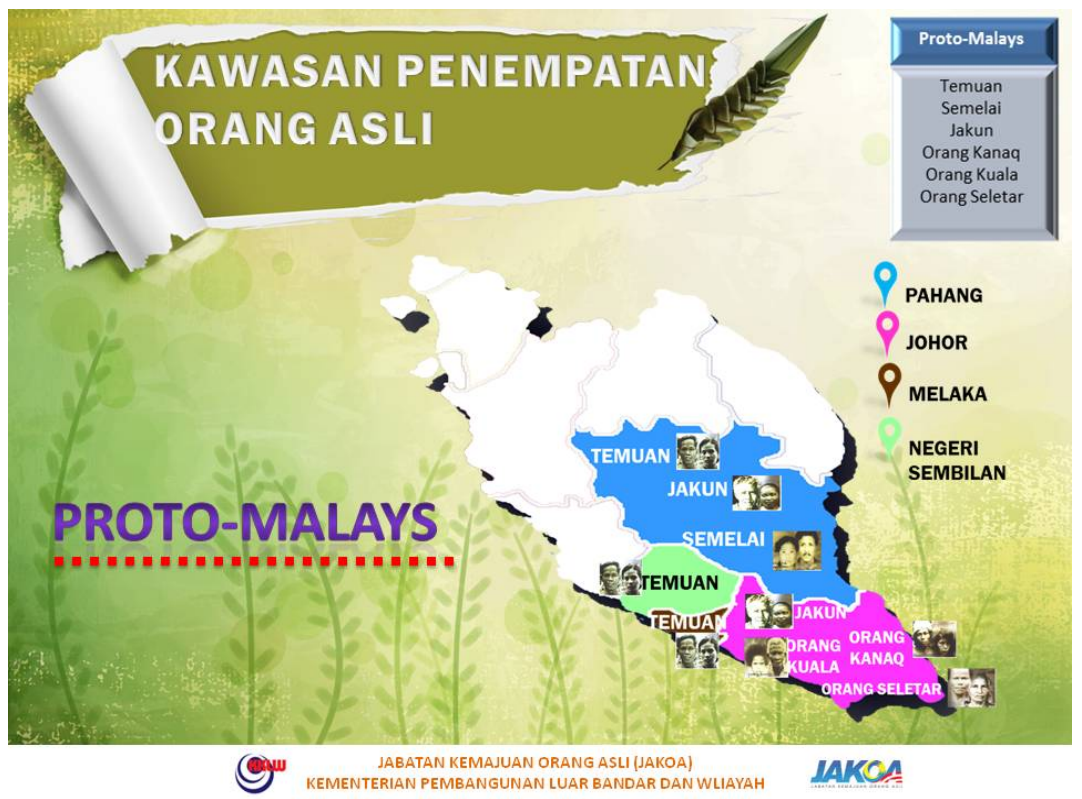

Source: http://si-kerdil-bersuara.blogspot.com/2018/06/masyarakat-orang-asli-di-semenanjung_7.html

In 1991, the Temuan population totalled about 2,148, and in 2010, the population was about 19,343 (Endicott 2016: 3). In Selangor, the Temuan community is concentrated in two districts, namely Kuala Langat (downstream) and Hulu Langat (upstream), and distributed around 13 villages (Tvedt \& Jakobsson 2006). Traditionally, the Temuan ply the Langat river and made use of the river as the main transportation system. They settled in villages along the river, at the upstream (Hulu Langat) and downstream (Kuala Langat) of the Langat river. But as the river water level subsided, they practised a settled existence, subsisting as hill paddy farmers, fruit and vegetable growers, inland fishermen, hunting and trading in forest products. In recent times, the Temuans work as wage earners in oil palm, rubber, government agencies and private companies (Tvedt \& Jakobsson 2006).

According to Tvedt \& Jakobsson (2006), the most outstanding social problems of the Temuan community are relative poverty and low income. It is estimated that about $80 \%$ of the Orang Asli communities live under absolute poverty, which makes them the poorest of the poor communities in Malaysia. Various reasons were given for their state of poverty, among others: non-recognition of legal rights to their land; marginalization despite rapid progress in mainstream society; exploitation and environmental degradation; monetization of the economy causing dispossession of land and relocation.

There is thus a need for more sustainable and equitable development poverty eradication strategy, for example, aggressive programme of sponsorship in education, equitable programme of land ownership, compensation plan for land acquisition, empowerment and participatory programme, and contribution from the private sector or agencies that has exploited their environment (Tvedt \& Jakobsson 2006).

Kampung Kachau Luar is an Orang Asli village from the Temuan community, located at Semenyih, about $25 \mathrm{~km}$ from Kajang town. Many of the children here dropped out of school (nearest school is Sekolah Kebangsaan Ulu Semenyih, which is about $8 \mathrm{~km}$ from the village). Kampung Gabai is also an Orang Asli village from the Temuan community, located at Dusun 
Tua, Hulu Langat. It is about $50 \mathrm{~km}$ from Kajang town (location of both villages as shown below).

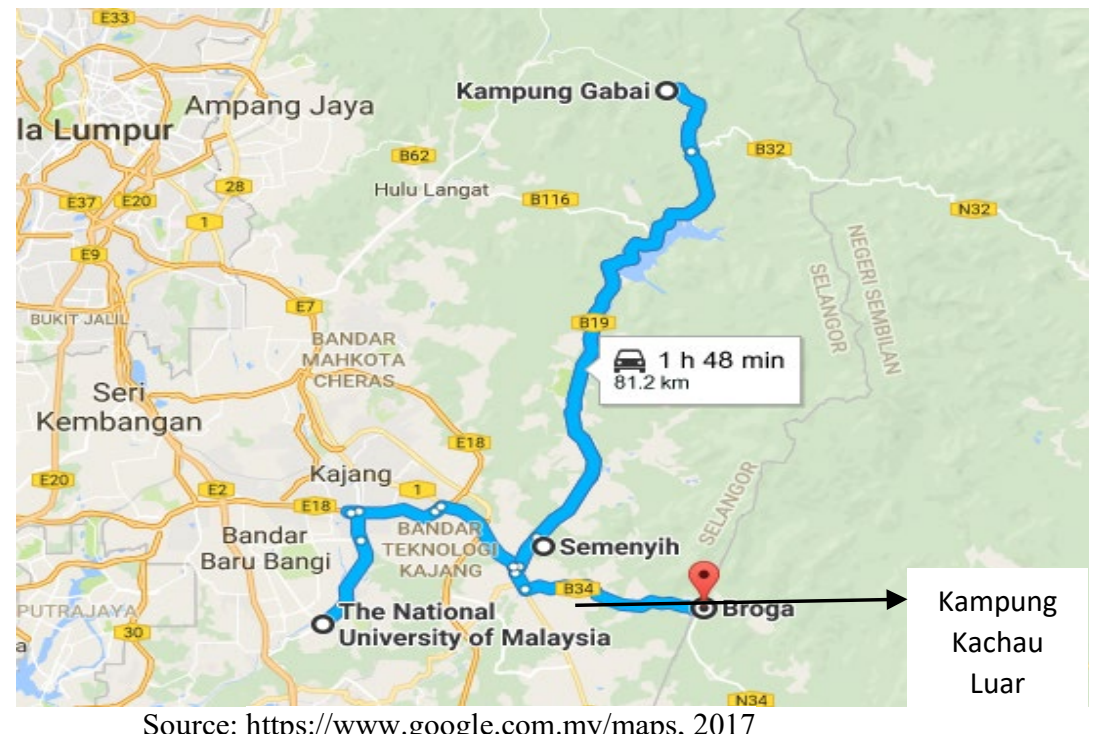

Kampung Kachau Luar has 35 households, with a population of about 138 people. Majority of its villagers are animists, with several Christian and Muslim families. Houses at Kampung Kachau Luar are single-story concrete houses. There are several abandoned houses. There is a community hall, which has a toilet and bathroom - all of which are not wellmaintained. The toilet and bathroom have water problem. There is a surau (village mosque) as some of the households are Muslims. Most of the households, however, are animists, and there are also several households who are Christians.

Kampung Gabai has 26 households, and about 150 people. Most of the families do village work, such as collecting forest products (buluh/bamboo, petai, fruits, rattan, bamboo shoots etc.), farm produce (durian, rambutan, vegetables) and bee rearing. Kg Gabai has been in existence since 1983, and most of the residents are related to one another, except for several people who come from elsewhere but married to Gabai villagers. Here at Gabai, there is a surau (village mosque) but no balai raya (community hall). Water supply is from the river, and there is electricity (metered). About half of the population have no toilets.

The education level for both Kampung Kachau Luar and Kampung Gabai is lower compared to the mainstream education level of non-Orang Asli. While more children of Kampung Kachau Luar go to school, the opposite happens for Kampung Gabai. Most children do not go to school. An in-depth household study could be conducted to understand the reasons why these Orang Asli children do not want to go to school. The reasons could include the living conditions, lifestyle, perception, attitudes as well as the school environment.

Nevertheless, one structural constraint could be the possession of formal identification documents. One pertinent issue connected with the lack of schooling among the Temuan children is identity cards (IC/MyKad) and birth certificates (as stated in the SUHAKAM Report 2011). For example, more than $20 \%$ of the villagers at Kampung Gabai do not have MyKad and/or birth certificates. Parents do not have IC, do not register their marriage, and pregnant mothers do not have 'Buku Merah' (Red Book) - a book to record their checkups 
during pregnancy, and after the birth. Why does this happen? Because there were women who gave birth in the village even though there was no midwife available. They gave birth by themselves with the help of other women, or sometimes, they didn't have time to go to the hospital. To get IC or even birth certificate is a tedious affair. The parents have to bring the child to the Department of Orang Asli Development (JAKOA) in Kajang in person because they have to sign or have their thumbprints taken. Without IC or formal identity documents, these Orang Asli adults and children could not leave their village without fear. One teenage girl said she does not leave the village and has never been to school because she has no formal identification papers.

Both Kampung Gabai and Kampung Kachau Luar are surrounded by beautiful scenery the Titiwangsa range. Kampung Gabai is located near the Gabai Waterfalls, while Kampung Kachau Luar is in the vicinity of Broga Hills. The Langat river with its tributaries such as Sungai Semenyih and Sungai Lui, is the major source of water supply. However, the Pangsun Dam, Langat Dam and Semenyih Dam have brought changes to the livelihood and lifestyle of the Temuan community. In the midst of lush greenery, abundant water supply and rich forest, the Temuans are living in poverty, marginalised from mainstream society, and placed under the care of JAKOA, which is said to be the 'father' of the orang asli people.

But in such a fundamental matter as issuance of birth certificates and identity cards, the Orang Asli community is facing a major obstacle. Many of them have no formal identification papers.

Many of the orang asli community have low level of education or no education at all. Many of the children registered for school, but do not attend school. There are those who do not register at all and have never stepped foot in a school (as in the case of Kg Gabai). Many of the students who went to school dropped out at a very early age (as in the case of $\mathrm{Kg}$ Kachau Luar).

In a study conducted by Doris et al. in 2012 in three Orang Asli villages (Kg Sungai Lalang Kachau Dalam, Semenyih, Selangor; Kg Sungai Ruil and Kg Pos Menson, Cameron Highlands, Pahang; and Kg Kerawat and Kg Sg Lalang, Simpang Pulai, Perak), it was found that the residents of these three villages have not been intensively exposed to training and education, especially in entreprenuerial development (Doris et al. 2012: 43).

\subsection{Penans of Murum, Sarawak}

The Penan children who participated in the literacy for social inclusion programs organized by DASwk come from Tegulang and Metalun, Murum, Belaga District, Sarawak. Both Tegulang and Metalun are resettlement villages for Penan and Kenyah communities who were affected by the construction of the Murum Dam which flooded their homes and lands. The project began in 2008 and was completed in 2013.

The map below shows the location of the two schools the Penan children in these villages attended - Tegulang Primary School and Metalun Primary School. Tegulang Primary School is more than five hours from its nearest city, Bintulu where part of the road after Anding is untarred logging track, as with the road from Tegulang to Metalun Primary School which would take more than two hours in good weather. 


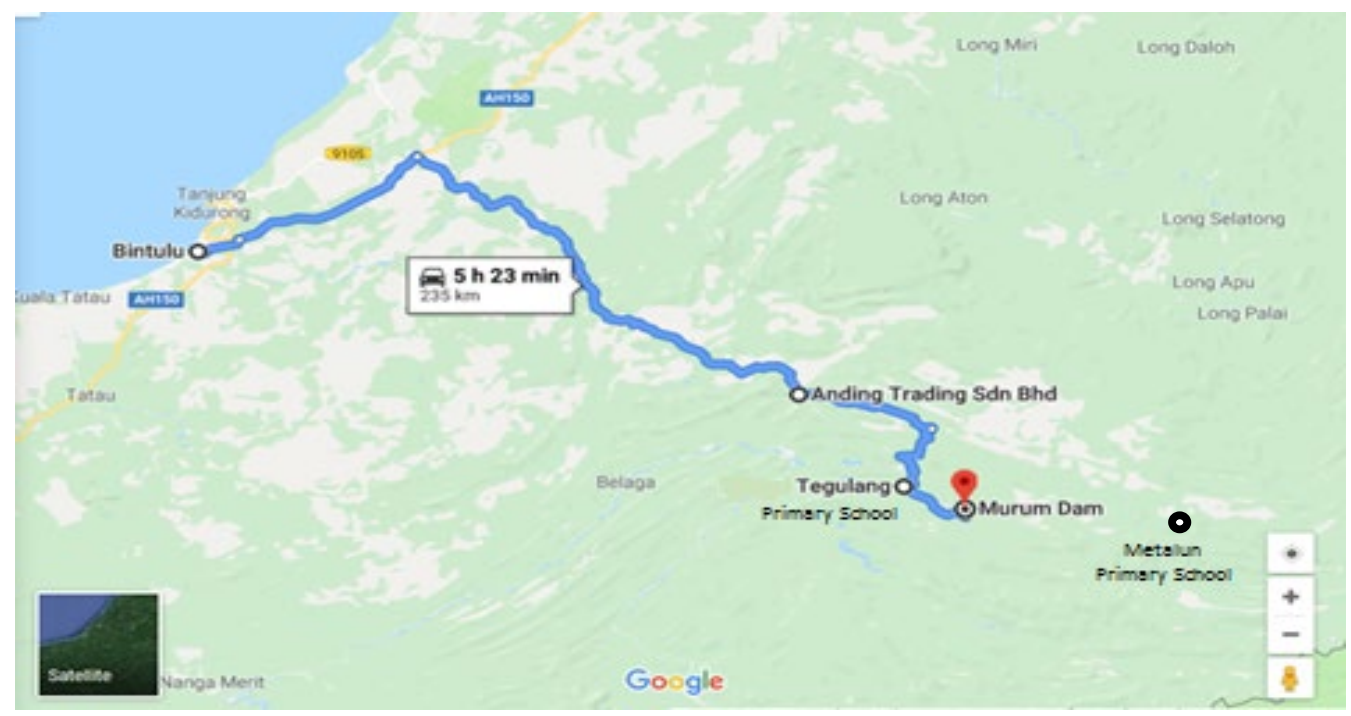

Source: https://www.google.com.my/maps, 2017

The Murum Hydroelectric Dam is located at the upstream of Rajang River, Belaga District, and in the middle of the Penan and Kenyah community's villages, who had been dependent on the forest for their livelihood. Its construction resulted in the relocation of 353 Penan and Kenyah families into seven villages with longhouses, six for Penan and one for Kenyah communities (Sarawak State Secretary Office 2016).

According to Langub (2008, cited in Chemsian Konsultant Sdn Bhd, Undated: C2), there were about 13,000 Penans in the whole of Sarawak. With the Baram River acting as the boundary, the Penan community is divided into two groups - West Penan and East Penan. The Penans who are residing around the Danum and Plieran Rivers are grouped under the West Penan category (Needham 1972, cited in Chemsian Konsultant Sdn Bhd, Undated: C2). The Penan community in the Belaga District has been residing at the valleys of Danum and Plieran Rivers since the 19th century (Brosius 1992, cited in Chemsian Konsultant Sdn Bhd, Undated: C2).

\subsection{The Sounds of Letters: SMARTER*Phonics ${ }^{\text {TM }}$ \& Foniks*PINTAR}

Due to time and infrastructural constraints, the literacy programme implemented among the Orang Asli Temuan children in Selangor in 2016 could not replicate the one-week programme conducted by DASwk in Sarawak. In addition, most of the Temuan children did not go to school or were dropouts. Hence, instead of a one-week training camp, we had a oneday (Sunday) once-a-month session for several consecutive months. Hence, the intensity and effectiveness of the programme conducted among the Temuan children in Selangor would not be as substantive and sustainable as the one-week programme conducted in Sarawak.

At Kampung Kachau Luar, Semenyih, we conducted four sessions of SMARTER*phonics for English (February, March, April \& May 2016), and four sessions of foniks*PINTAR for Bahasa Melayu (June, July, August \& September 2016). At Kampung Gabai, Dusun Tua, we conducted five sessions of foniks*PINTAR (February, March, April, July \& August 2017). 
SMARTER $^{*}$ phonics ${ }^{\mathrm{TM}}$ (and foniks*PINTAR) is a structured, gradual, repetitive approach, using phonics and multi-sensorial methods, and designed to enable students to sound out letters by segmentation and blending.

\section{What is phonics?}

Phonics refers to the relationship between letters and the sounds they make. This knowledge is essential to a child's ability to sound out, or decode, and to spell, or encode words. Phonics also includes the rules in this relationship.

Children are taught sound-letter (or specific letter combination like /kh/, /ng/) correspondence so when they hear a letter sound, they can match it to the letter or letter combination and when they see a letter or specific letter combination, they can say its sound. They are taught the principles of blending from left to right where the sound of the first letter or letter combination merges seamlessly into that of the following letter or letter combination. This is decoding, sounding out while reading a word. The children are taught specifically the principles of segmenting where when they hear a word, they identify the letter sounds in sequence from left to right, match them to their letters or letter combinations and to write them down. This is encoding, writing a word that is heard. The children then use these processes of decoding and encoding to read and write. Repeated practice soon cultivates accuracy and fluency.

This is the first important step in learning to read. Phonics is a way of teaching children to read quickly and skillfully (Department of Education, UK 2013).

Why phonics?

Research shows that when phonics is taught in a structured way - starting with the single letter sounds and progressing through to blending and segmenting of $\mathrm{CV}, \mathrm{VC}, \mathrm{CVC}$ and longer words $(\mathrm{C}$ - consonant, $\mathrm{V}$ - vowel) and then to phrases, short sentences and passages it is the most effective way of teaching young children to read. It is particularly helpful for children aged 5 to 7 . Almost all children who receive good teaching of phonics will learn the skills they need to tackle new words. They can then go on to read any kind of text fluently and confidently, and to read for enjoyment. Children who have been taught phonics also tend to read more accurately than those taught using other methods, such as 'look and say'. This includes children who find learning to read difficult, for example those who have dyslexia (Department of Education, UK 2013).

Effective phonics instruction is important because letter-sound knowledge is the foundation needed to build up reading and writing abilities (The Conversation 2018).

Research has also shown that the phonics method (using letter sounds) is effective for early and struggling readers. This phonics method is vouched for in the world-renowned Orton-Gillingham reading programs (The Academy of Orton-Gillingham Practitioners and Educators Undated). The U.S.'s National Reading Panel (2000) vouched for the superiority of phonics and phoneme manipulation in teaching any young children of any age group to learn to read and write in English and other alphabetic languages. Various brain research have provided evidence that phonics training increases activity in the areas of the brain specialized for reading (McCandliss 2010; Boets et al. 2013; Dehaene 2013).

For SMARTER*phonics ${ }^{\mathrm{TM}}$ and foniks*PINTAR, learning to read the phonics way is aided by the use of bottle caps with letters (consonants and vowels) written on each of them, and tactile mats, both to facilitate brain activity and corresponding psychomotor movements, as shown in Photos 1 and 2: 


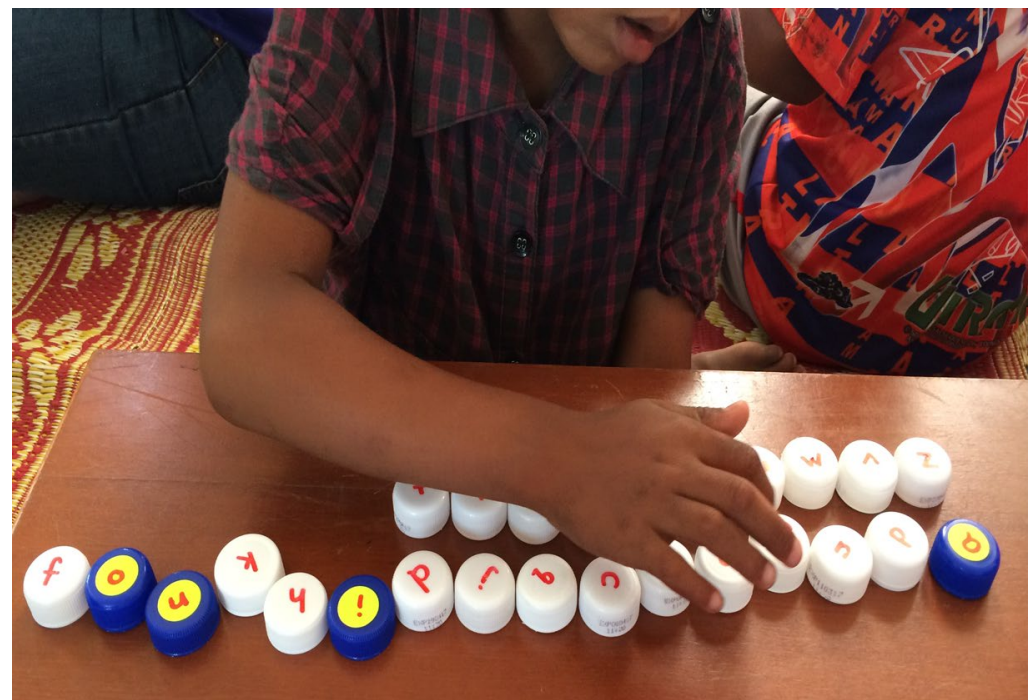

Fig 1. Bottle caps as concrete aids to learn to read, spell and write, especialy for struggling readers (photo credit: Ong Puay Liu)

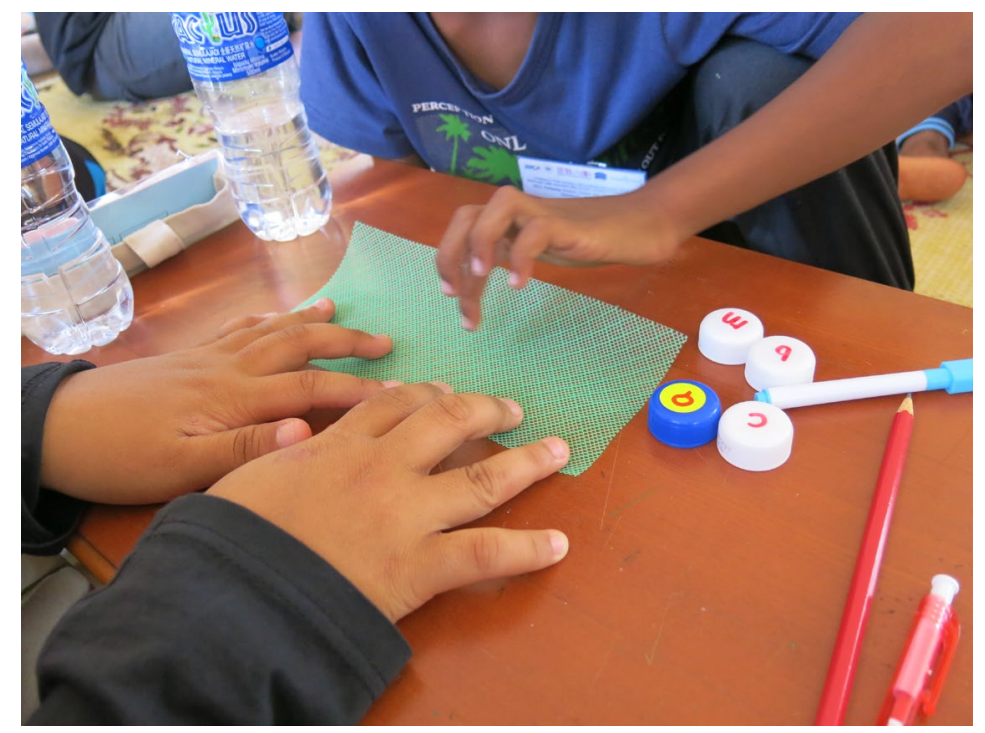

Fig 2. Tactile mat - another concrete aid to learn to read, spell and write (photo credit: Ong Puay Liu)

As mentioned above regarding the one-week intensive reading camp conducted by DASwk using this innovative, highly structured, phonics-based and multi-sensorial reading programme (SMARTER* phonics $^{\mathrm{TM}}$ ) with nine-year old children undergoing remedial education in their schools, they were able to read at their age-appropriate level at the end of the camp and two months after the camp. This shows that the innovative phonics-based reading programme which uses bottle caps as a physical manipulative aid that DASwk 
developed could be an effective programme to nurture and enhance decoding skills of beginning and struggling readers.

\section{Program Structure}

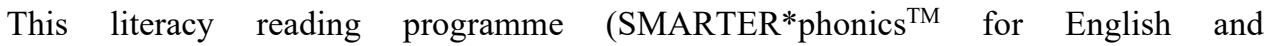
foniks*PINTAR for Bahasa Melayu) has been developed to build reading skills of children in Primary 1 to Primary 3. Based on a gradual approach, each student will learn to recognise letters (consonants and vowels) by their individual sounds (phonics) through the encoding and decoding process, and to blend these individual sounds so as to form parts of a word, then, a word. Bottle caps are used to present vowels, consonants and their combinations in a gradual, cumulative, progressing with increasing difficulty and complexity in four levels as follows:

Level 1: C,V, CV, CVCV and VCV words (C - consonants, V - vowels)

Level 2: CVC, CVCVC and CVCVCV words. Short phrases and sentences

Level 3: CVV, CVCVV and words with 'ng'. Short phrases and sentences

Level 4: Words with 'ny'. Short passages.

The appropriate words, phrases, sentences and story lines in the form of short passages will be constructed on the vowel/consonant combinations into a phonics-, multi-sensorial- and multimedia-based reading programme. Each level of reading skills will be represented by one set of book and its accompanying workbook and worksheets in both print and multimedia formats.

For SMARTER* phonics $^{\mathrm{TM}}$ programme, the complementary learning aids are:

a. a set of story-based Fitzroy books

b. a laminated abc card

c. a word list $(\mathrm{CV}, \mathrm{VCC}, \mathrm{VC} \& \mathrm{CVC}$ syllables words; CCVC, CVCC, CCVCC words \& words with double ls (1l); Bossy $\mathrm{r}$ words; Magic-e words; Two- \& three-syllable words;

Vowel team words; Diphthong words; y as long vowel i, e, a)

d. a set of bottle-caps representing each letter (26) in the alphabet

e. a tactile mat

f. a white board and whiteboard markers

g. pocket chart with letter cards

h. an exercise book

i. a skipping ropes and hula hoops

For foniks*PINTAR programme, the set of story-based Fitzroy books and the word list are replaced by a set of ten books in Bahasa Melayu (each book defined by differentiated progressive levels). This set of foniks*PINTAR books is developed by the President of Dyslexia Association of Sarawak (DASwk), Ong Puay Hoon.

The main learning-to-read activity is interspersed with physical and movement activities that include brain gym exercises, rope skipping, foot drills, hula hooping and ball games, storytelling sessions, which entail drama performances and singing sessions.

To assess students' progress, a pre-test is taken by participants before the commencement of each programme and a post-test at the end of the programme. The outcomes of these assessments will be displayed in a graphical manner.

Each student-participant receives a bag that contained the following:

a. one exercise book with songs and stories pasted 
b. one laminated abc card

c. a set of words to be learnt - ring-bound

d. one set of bottle-caps representing each letter in the alphabet

e. one tactile mat

f. short sentences

Each participant is required to bring this kit when we have our monthly reading sessions, and to have his/her own set of writing materials (pencils, colour pencils, ruler, eraser). The monthly sessions start at $8.30 \mathrm{am}$, followed by tea break at $10 \mathrm{am}$, and lunch at $12.30 \mathrm{pm}$, and ending by about $3.30 \mathrm{pm}$.

\section{Results And Discussion}

This section will present pre- and post-test results for English and Bahasa Melayu for Orang Asli Temuan children in Selangor and Penan children of Murum, Sarawak.

The pre- and post-test in Bahasa Melayu has six sections:

- $\quad$ arrange letters from a-z

- write letters from a-z

- $\quad$ reading the given words in one minute

- $\quad$ reading the given words without time limit

- $\quad$ spelling

- comprehension

The pre- and post-test in English has nine sections:

- $\quad$ arrange letters from $\mathrm{a}-\mathrm{z}$

- read letters from $a-z$

- $\quad$ write letters from a-z

- $\quad$ read DOLCH sight words

- $\quad$ spell DOLCH sight words

- $\quad$ read CVC and other phonetic words

- $\quad$ spell CVC and other phonetic words

- read non words

- comprehension

For the Orang Asli Temuan children, there will be two sets of data:

a. monthly sessions in 2016-2017: pre- and post-test results for English and Bahasa Melayu for Kampung Kachau Luar, Semenyih (Graph $1 \&$ Graph 2) and the pre- and post-test results for Bahasa Melayu for Kampung Gabai, Dusun Tua (Graph 3).

b. two one-week foniks*PINTAR camps (Camp 1.0 \& Camp 2.0) in 2018: pre- and posttest results for Bahasa Melayu (Graph 4)

For Penan children, there will be one set of data:

a. two one-week foniks*PINTAR camps (Camp 1.0 \& Camp 2.0) in 2018: pre- and posttest results for Bahasa Melayu (Graph 5) 


\subsection{Pre and Post-Test Results in English, Kampung Kachau Luar, Semenyih (2016)}

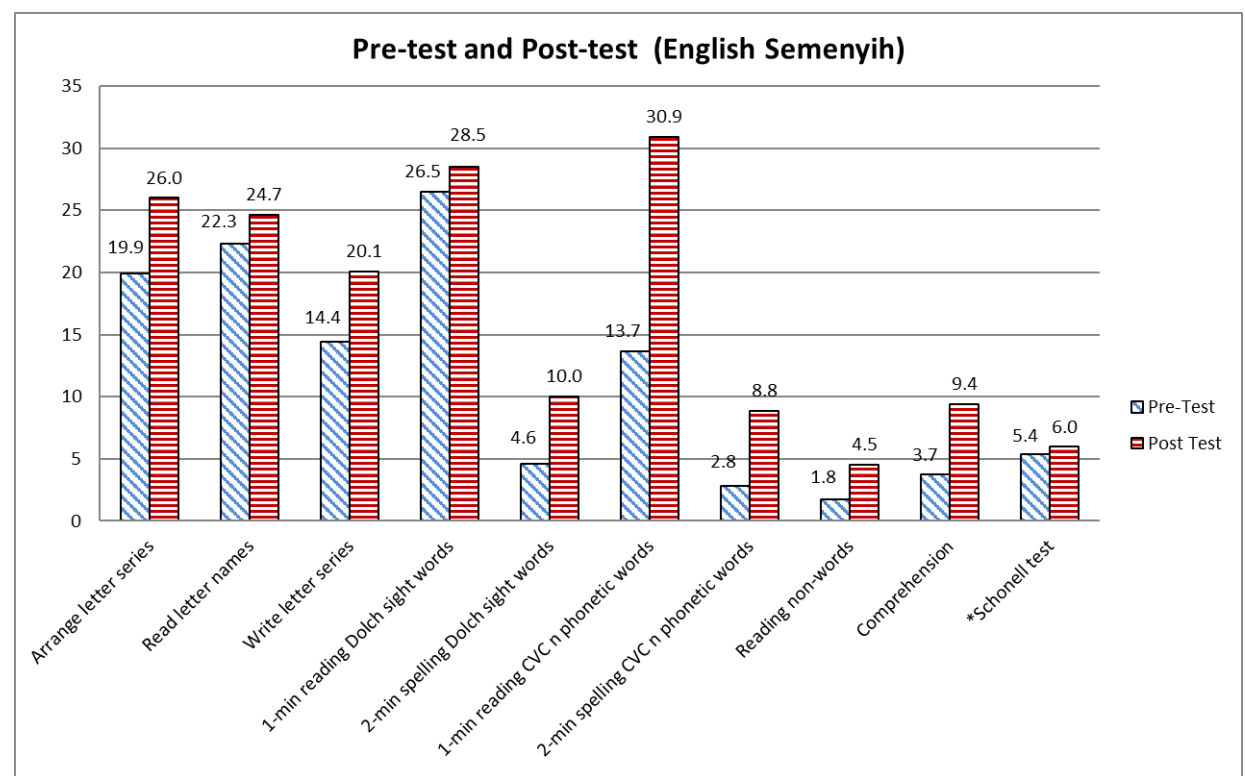

Graph 1. Pre and Post-test results for English (BI), Kg Kachau Luar, Semenyih (2016)

Graph 1 above presents the results for both pre- and post-tests in English conducted at Kampung Kachau Luar. A total of 28 participants took the pre-test in February 2016, which was the first session of the programme, and 16 participants did the post-test conducted in May 2016.

Overall, a comparison of the average pre-test and post-test results for English indicate a great improvement for all the nine sections tested. For example, the average number of letters that the 28 participants could arrange correctly was 19.9 letters for pre-test and 26.0 letters for post-test. For number of letters that the participants could read, the average score for pre-test was 22.3 and for post-test, the score was 24.7. For reading CVC words and other phonetic words, the increase in average score was quite dramatic. The pre-test average score was 13.7 words and the post-test score was 30.9 words. The reading age, however, for the participants aged between 6-19 years old was only 5.4 years for pre-test and 6.0 years for post-test.

Graph 2 below shows the Kampung Kachau Luar pre-test and post-test results for Bahasa Melayu. The pre-test was conducted in June 2016 while the post-test in September 2016. As the participants had done the test in English, for the pre-test in Bahasa Melayu (BM), we skipped the items for arranging and writing the letters from a-z (menyusun huruf $a-z$ dan menulis huruf $a-z$ ). Twenty participants did the BM pre-test, while 15 participants took the BM post-test.

The scores in Graph 2 indicate a slight improvement in average scores for the BM preand post-tests for the items 'membaca dalam 1 minit' (1 minute reading), 'membaca tanpa had masa' (reading without time limit) and 'kefahaman' (comprehension).

For the English pre-test, the average score for arranging letters a-z was 19.9, and for posttest, the average score was 26.0 (Graph 1). Comparing with the post-test score for Bahasa Melayu, the average score was 23.2 (Graph 2). While the score is higher than the pre-test 
score, it has decreased when compared to the post-test score, considering that the English post-test was done in May, and the BM pre-test was taken in September.

For writing the letters a-z, the English pre-test average score was 22.3 and post-test score was 24.7 (Graph 1). For the BM post-test, the average score was 23.9 (Graph 2), depicting a similar pattern with the item arranging letters a-z. The average score indicates that there are some participants who are still struggling with letter recognition.

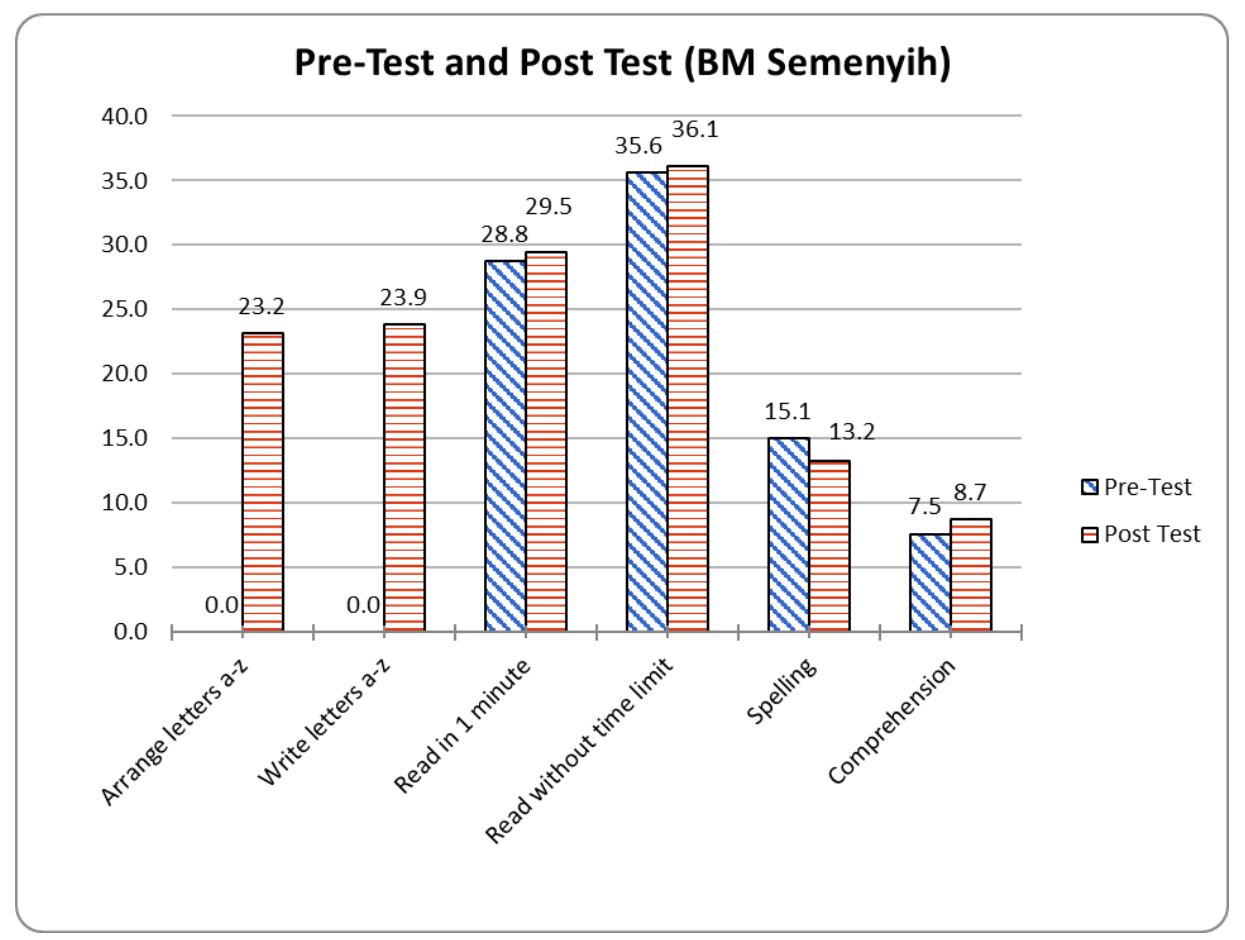

Graph 2 Pre and Post-test results for Bahasa Melayu (BM), Kg Kachau Luar, Semenyih (2016)

3.2 Pre- and Post-Test Results in Bahasa Melayu, Kampung Gabai, Dusun Tua (2017)

The pre-test was carried out in February 2017, the first session of the programme, and the post-test in August 2017. Graph 3 below presents the average scores for both pre- and posttest results for the six items tested.

Twelve participants took the pre-test for Bahasa Melayu. Only four (33\%) out of this 12 participants go to school. One out of this four school-going students scored zero for all the six items tested. This student is eight years old and attending a primary school. One teenager who had never gone to school could arrange and write the letters from a-z (25 out of 26 letters correct). However, for the other four items, her scores were very dismal.

Out of 12 students who took the pre-test, eight of them scored zero for all the six sections tested. The average score for arranging letters $\mathrm{a}-\mathrm{z}$ was 7.3 and for writing the letters $\mathrm{a}-\mathrm{z}$ was 7.2. The score for one-minute reading was 5.7, while spelling was 2.3 .

All but three of the 12 students could not read the two passages for comprehension. Only one student out of the 3 students could read on her own without the help of the tester. This student is 12 years old, Primary Six, and could read very well as well as understand the passages. 
The post-test results show that there is significant improvement between pre- and post-test average scores for three items tested, that is, arranging letters from a-z (from 7.3 to 17.7), writing the letters from a-z (from 7.2 to 16.3) and comprehension (from 1.4 to 6.4). The students might not be able to read the passages and they needed the facilitators' help to read. Nevertheless, they seemed to understand the passages. For reading within one minit, the score results remained the same (5.7) while for spelling, there is a decrease from an average score of 2.3 to 1.3 .

Overall, the average score results for pre- and post-test results for the $\mathrm{Kg}$ Gabai students are impressive considering the fact that most of these students do not go to school at all.

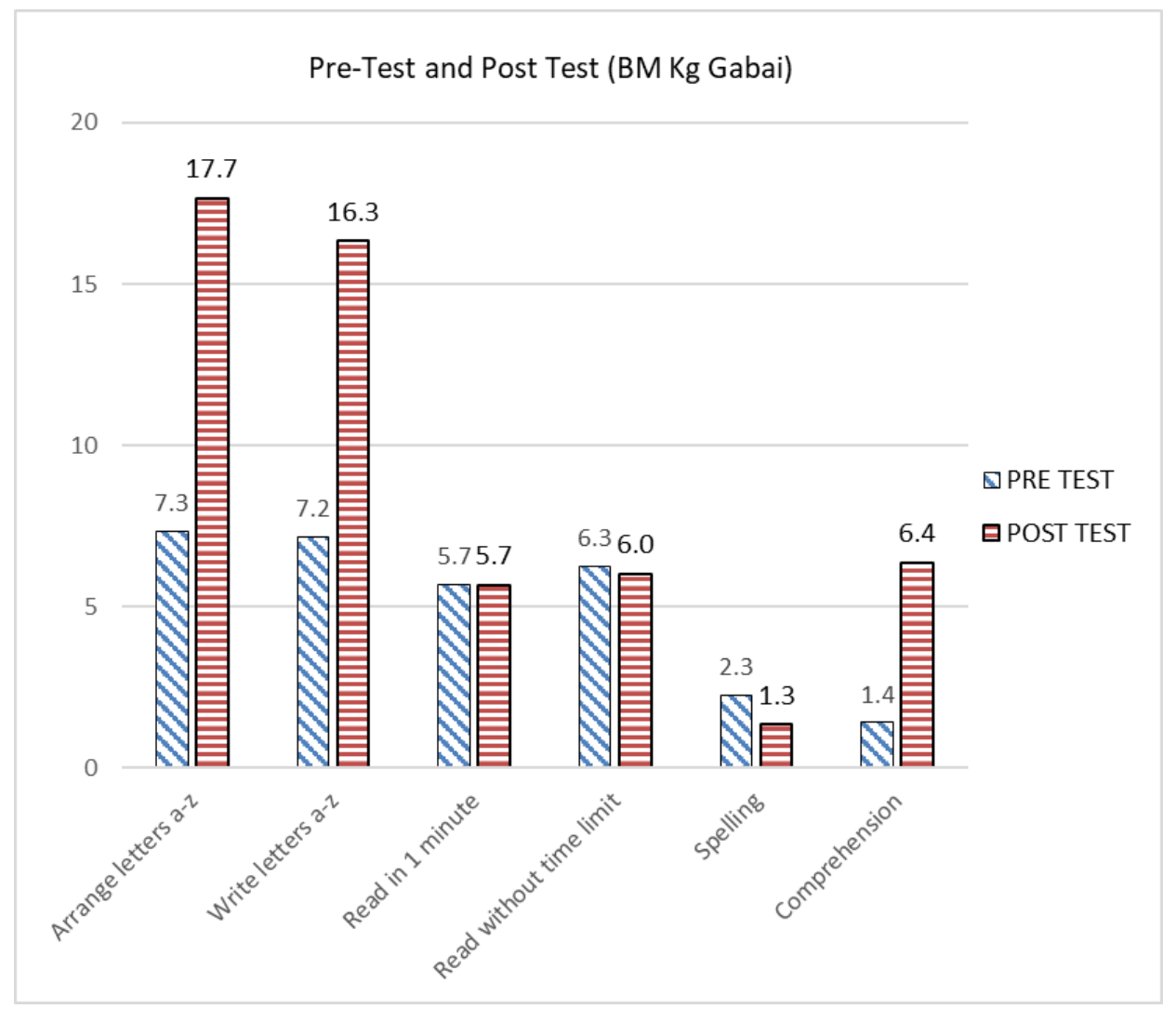

Graph 3 Pre- and Post-test results for Bahasa Melayu, Kg Gabai, Dusun Tua (2017) 


\subsection{One-Week Bahasa Melayu Literacy Camp for Orang Asli Temuan Children (March \& August 2018) and Penan Children (May \& July 2018)}

Two Bahasa Melayu (BM) one-week literacy camps, titled 'Empowering Children of Two Marginalized Communities through Literacy for Social Inclusion and Mobility' were held on 16-22 March 2018 (Temuan Camp 1.0), at Kem PLKN Millennium, Beranang, Selangor, while the second camp was held on 18-24 August 2018 (Temuan Camp 2.0). This programme is an extension to the once-a-month literacy program conducted by DASwk in 2016 at Kampung Kachau Luar, Semenyih, Selangor (English and Bahasa Melayu program) and 2017 at Kampung Gabai, Dusun Tua, Selangor (Bahasa Melayu [BM] program).

For the Penan children, Camp 1.0 was held on 13-19 May 2018 while the second camp was held on 2-7 July 2018.

This one-week literacy camp, conducted in stay-in and away-from-home format, provided an intensive and immersive environment for the mastery of reading and writing in BM among the targeted children, using the foniks*PINTAR reading programme.

Graph 4 presents the pre-test, progressive and post-test results for the two one-week foniks*PINTAR camps for Orang Asli children (Temuan Camp 1.0 \& Camp 2.0), while Graph 5 presents the results for Penan children (Penan Camp 1.0 \& Camp 2.0).

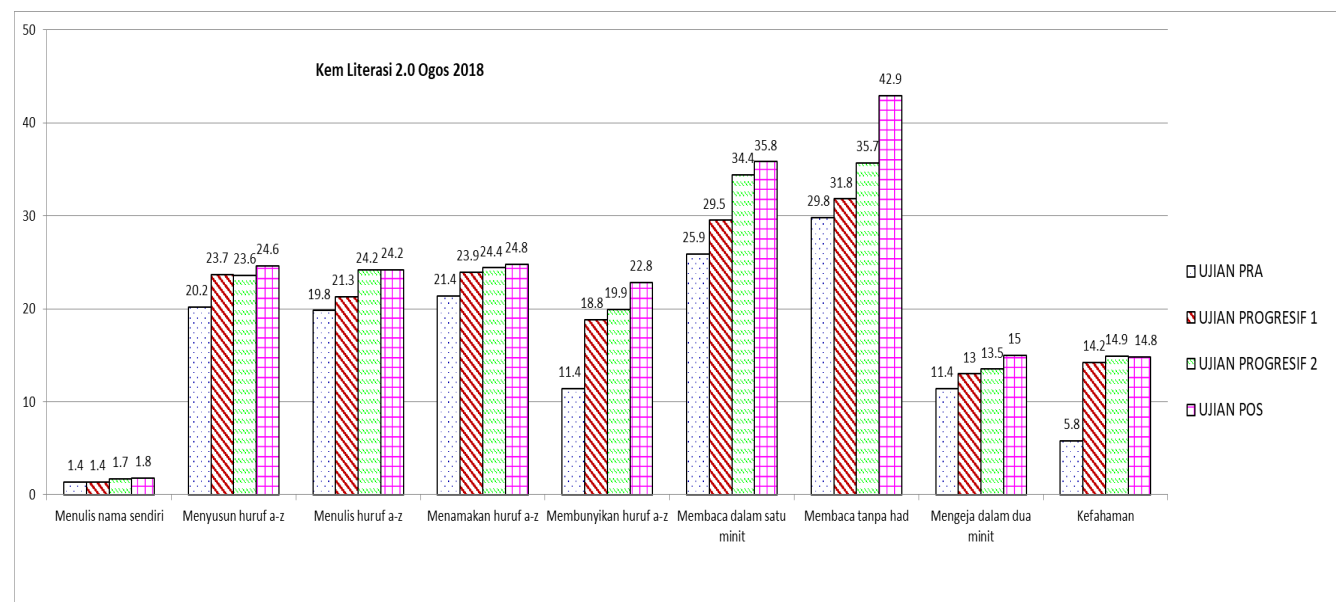

Graph 4 Distribution of skills attainment for pre-test and progressive test 1 (Temuan Camp 1.0) and progressive test 2 and post-test (Temuan Camp 2.0) 


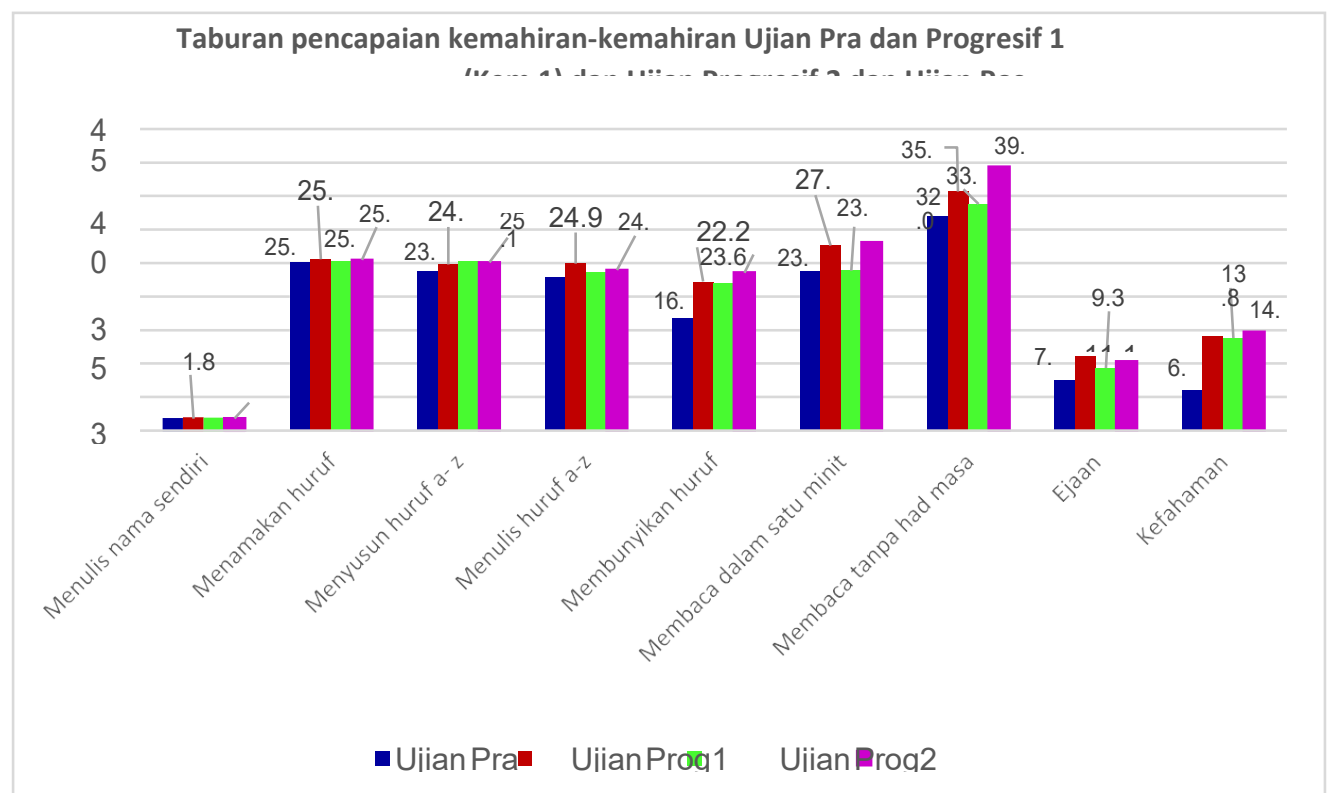

Graph 5 Distribution of skills attainment for pre-test and progressive Test 1 (Penan Camp 1.0) and progressive test 2 and post-test (Penan Camp 2.0)

\subsection{Reflections and Conclusion}

Both the SMARTER * phonics $^{\mathrm{TM}}$ and foniks*PINTAR programmes focus on reading using the phonics method and based on a multi-sensorial approach. Children are thus exposed to a variety of ways of learning to read, spell and write using all the five senses plus one, that is, their brain. In the process, these children learn that reading is actually fun! They are encouraged to use bottle caps to recognize letters by name and sound; use tactile mat to trigger nerves on their fingers when they write letters and spell words on the mat; sky-write to visualize the letters in abstract form; learn hand-leg-eye-ear-mind coordination. Graphs 1-5 show that there is improvement and progress in reading, spelling, writing and comprehension. More significantly, there is positive difference between pre-test and post-test. We can infer from this that the monthly sessions as well as the one-week camps have generated more positive results.

But much more needs to be done to make this progress sustainable. This sustainability will not happen without continuity in school and in the home.

To have quality education (as stipulated in the Education Blueprint) is the basic foundation to improve quality of life and sustainable well-being. At the international level, enrolment rate to primary schools in developing countries have reached $91 \%$, nevertheless, it is disheartening to note that some 57 million children of school going age are not going to school.

Malaysia's Orang Asli and Penan children are included in this statistic of non-school going children.

The importance of the right to education represents the connectedness between all human rights (UNESCO 2014 in Ong et al 2016). The right to education of all children, youths, young adults and adults is endorsed and supported by the Universal Declaration of Human Rights 1948 and the Convention on the Rights of the Child 1989. The education received 
should enable the children to develop their talents and potential, as well as shaping their character, so that they can improve their life (UNESCO 2000: 8) and well-being and be an asset to their community, society and nation.

Orang Asli and Penan children have the same aspirations as non Orang Asli children. They want to go to school, but a myriad of factors acts as obstacles to encourage them from going to school. They too desire comfort and happiness, growth and development in their midst. One important institution that can help them realise their aspirations is education. As stated in the SUHAKAM report, there are many obstacles hindering the Orang Asli (and Penan) children's path to education and attainment of a quality of education worthy of their aspirations. The government, Federal and State, schools as well as non-governmental organisations, could think of other ways to encourage Orang Asli and Penan children to go to school and stay in school. If Orang Asli and Penan children do not want to go to school, then could there be a way where 'the school goes to the Orang Asli and Penan'?

The once-a-month sessions with the Orang Asli children of Kampung Kachau Luar and Kampung Gabai as presented above has this objective in mind, that is, to bring the 'school to the Orang Asli children'. The improvement in reading as shown by the pre- and post-test results indicate that these Orang Asli children can learn and are willing to learn given the conducive environment and appropriate teaching-learning methodology.

Through the one-week foniks*PINTAR literacy camps for the Orang Asli and Penan children, the 'school' is brought to the children, albeit not in the comforts of their respective villages. Instead, we brought them to a neutral place where they could focus on the programme and make new friends. The feedback from these two one-week camp participants was very favourable. It not only improved their reading abilities through the usage of phonics, but more significantly, their ability to read has fostered their confidence and impacted the way they see themselves.

There will be a third camp for the Orang Asli Temuan children to be held on 12-18 August 2019 at UKM Bangi. This camp will be an English camp based on the SMARTER* ${ }^{*}$ honics ${ }^{\mathrm{TM}}$ programme. About 16 children from Kampung Kachau Luar, most of whom had attended Camps 1.0 and 2.0, have registered for camp 3.0. It is hoped that camp 3.0 will enhance and develop further their phonetic awareness and reading skills in English, as well as strengthening their self-confidence and self-esteem.

\section{Acknowledgements}

Gratitude and expression of thanks to the:

US Embassy, Kuala Lumpur (funding for project Literacy for Social Inclusion 2016-2017); EDGE KL Rat Race 2017 (funding for project Empowering Children of Two Marginalised Communities through Literacy for Social Inclusion and Mobility 2018, research code: RE2018-002); JAKOA; Dyslexia Association of Sarawak; Institute of Ethnic Studies (KITA), UKM; LESTARI-UKM (research code KRA-2017-020); Multimedia University Melaka; Islamic Outreach ABIM; Kem PLKN Millennium, Beranang; Kolej Dato Onn, UKM; Majlis Kebajikan Sosial Sarawak; Sarawak Energy Bhd. (SEB); Jabatan Pendidikan Negeri Sarawak, Parents, teachers, students and children from both Penan and Temuan communities; and to all our assistant trainers, facilitators, volunteers and sponsors. 


\section{References}

[1]. Adiseshiah, Malcolm S. 1990. Illiteracy and Poverty. Literacy Lessons. Geneva: International Bureau of Education.

[2]. Boets, B., Op de Beeck, H.P., Vandermosten, M. et al. (2013). Intact but Less Accessible Phonetic Representations in Adults with Dyslexia. Science. 342(6163): 1251-1254.

[3]. Brunner, Michael S. 1993. Retarding America: The Imprisonment of Potential. Halcyon House.

[4]. Center for Orang Asli Concerns. 2012. About the Orang Asli: Basic Data/Statistics. http://www.coac.org.my/main.php?section=about\&article_id=4

[5]. Chemsian Konsultant Sdn Bhd. Undated. Social and Environmental Impact Assessment for the Murum Hydroelectric Power Project. Contemporary Ethnography.

[6]. Dehaene, Stanislas. 2013. Inside the Letterbox: How Literacy Transforms the Human Brain. Cerebrum May-June, 7. https://www.ncbi.nlm.nih.gov/pmc/articles/PMC3704307/. Retrieved on: 5 January 2018.

[7]. Department for Education, UK. 2013. Learning to read through phonics: Information for parents. https://assets.publishing.service.gov.uk/government/uploads/system/uploads/attachment_data/file/1 94057/phonics_check_leaflet_2013_pdf. Retrieved on: 30 July 2018.

[8]. Department of Statistics, Malaysia. 2013. Laporan Ciri-Ciri Pendidikan dan Sosial Penduduk 2010. http: www.statistics.gov.my. Retrieved on: 10 February 2017.

[9]. Endicott, Kirk. 2016. Malaysia's Original People: Past, Present and Future of the Orang Asli. Singapore: NUS Press.

[10]. Fountas, Irene C. \& Pinnel, Gay S. 1999. Voices on Word Matters: Learning about Phonics and Spelling in the Literacy Classroom. Portsmouth, N.H: Heinemann.

[11]. Google Map to $\mathrm{Kg}$ Gabai and $\mathrm{Kg}$ Kachau. 2017. https://www.google.com.my/maps/dir/The+National+University+of+Malaysia+Bangi+Selangor/Se menyih,+Selangor/Broga,+Semenyih,+Selangor/Air+Terjun+Sungai+Gabai/@3.0320924,101.694 $9171,11 \mathrm{z} /$ data $=! 3 \mathrm{~m} 1 ! 4 \mathrm{~b} 1 ! 4 \mathrm{~m} 26 ! 4 \mathrm{~m} 25 ! 1 \mathrm{~m} 5 ! 1 \mathrm{~m} 1$ ! $1 \mathrm{~s} 0 \times 31 \mathrm{cdc} 926$ aaaaaab:0xed49c9d40bf42563!2 $\mathrm{m} 2$ !1d101.7774225!2d2.929997!1 m5!1m1!1s0x31cdce7fd6c57495:0x8d2167eda5ade6e3!2m2!1d 101.8451441 !2d 2.947441 ! $1 \mathrm{~m} 5$ ! $1 \mathrm{~m} 1$ ! $1 \mathrm{~s} 0 \times 31 \mathrm{cdd} 1 \mathrm{eb} 38 \mathrm{~b} 51 \mathrm{ba} 5: 0 x 46 \mathrm{f} 9 \mathrm{f} 949509 \mathrm{bd} 583$ !2m 2 ! $1 \mathrm{~d} 101.91$ 11479 !2d2.93669!1m5!1m1!1s0x31 cc2fc1ab3a8dc7:0xb0fa9fa078d351ff!2m2!1d101.9090289!2d $3.1660921 ! 3 \mathrm{e} 0$ ?hl=enRetrieved on: 12 May 2017.

[12]. Hasan Mat Nor. 1997. Kajian Keciciran Kalangan Pelajar Orang Asli Peringkat Sekolah Rendah (Drop-out Report of Orang Asli Primary School Children). Jabatan Anthropologi dan Sosiologi. Universiti Kebangsaan Malaysia, Bangi.

[13]. Hogenson, Dennis L. 1974. Reading Failure and Juvenile Delinquency. Bulletin of the Orton Society, 24: 164-169.

[14]. Jabatan Kemajuan Orang Asli (JAKOA). 2016. Program JAKOA: Pengenalan. http://www.jakoa.gov.my/orang-asli/program-jakoa/. Retrieved on: 12 February 2017.

[15]. Kang Soon Chen. 2012. LINUS Programme for Early Learning. Star Online. 5 September 2012. http://www.thestar.com.my/News/Nation/2012/09/05/LINUS-programme-for-early-learning. Retrieved on: 11 October 2015.

[16]. Lasimbang, J. 2016. Malaysia. In IWGIA (2016). The Indigenous World. International Work Group for International Affairs. http://www. iwgia.org/regions/asia/malaysia. Retrieved on: 10 January 2017.

[17]. Malaysia. 2006. Laws of Malaysia [Reprint] Act 134 Aboriginal Peoples Act 1954, Incorporating all amendments up to 1 January 2006 . http://theredddesk.org/sites/default/files/aboriginal_act_134.pdf. Retrieved on: 12 February 2017.

[18]. Memorandum Terbuka Masyarakat Penan Murum, Daerah Belaga, Bahagian Kapit, Sarawak kepada YAB Datuk Seri Najib Tun Razah dan YAB Pehin Seri Hj Abdul TAib Mahmud. 25 September 
http://sarawak.s3.amazonaws.com/murum/Memorandum\%20Terbuka\%20Masyarakat\%20Penan\% 20Murum.pdf

[19]. Memorandum Terbuka Masyarakat Penan Murum, Daerah Belaga, Bahagian Kapit, Sarawak kepada YAB Datuk Seri Najib Tun Razah dan YAB Pehin Seri Hj Abdul TAib Mahmud. 25 September http://sarawak.s3.amazonaws.com/murum/Memorandum\%20Terbuka\%20Masyarakat\%20Penan\% 20Murum.pdf

[20]. Ministry of Education. 2013. Malaysia Education Blueprint 2013 - 2025 (Preschool to PostSecondary Education). Putrajaya: Ministry of Education.

[21]. MURUM Hydroelectric Power Project Resettlement Action Plan Final Report November, 2011. https://hornbillunleashed.files.wordpress.com/2012/11/murum-hydroelectric-power-projectresettlement-action-plan.pdf

[22]. National Reading Panel. 2000. Report of the National Reading Panel: Teaching Children to Read. Washington, DC: National Institutes of Health.

[23]. Nicholas, C. 2000. The Orang Asli and the Contest for Resources: Indigenous Politics, Development \& Identity in Peninsular Malaysia. Copenhagen: International Work Group for International Affairs.

[24]. Nicholas, Colin, 2012. A Brief Introduction: The Orang Asli of Peninsular Malaysia. http://www.coac.org.my/main.php?section=about\&page=about_index. Retrieved on: 12 February 2017.

[25]. Nordtveit, B.H. 2008. Poverty Alleviation and Integrated Service Delivery: Literacy, Early Child Development and Health. International Journal of Educational Development, 28(4): 405-418.

[26]. Ong Puay Liu, Mary Tang Siew Ing, Ong Puay Tee and Audrey ak William. 2016. The Right to Read for All Children: The Effectiveness of a Multisensory and Phonics-based Instruction Programme. Paper presented at the $10^{\text {th }}$ International Malaysian Studies Conference (MSC10), 15 17 August 2016, UMS Kota Kinabalu, Sabah, organised by the Malaysian Social Sciences Association.

[27]. Ong, P.H., Lee, B.L.W., Lissen. W.A., Persad, C., Ong, P.L. \& Ong, P.T. 2014. The use of ubiquitous bottle caps as concrete aids to learn to read and spell for struggling readers. A poster presentation in the Annual Reading, Literacy and Learning Conference of the International Dyslexia Association, San Diego, United States, 12-15 November 2014.

[28]. Rosen, Peg. 2016. Orton-Gillingham: What you need to know. https://www.understood.org/en/school-learning/partnering-with-childs-school/instructionalstrategies/orton-gillingham-what-you-need-to-know. Retrieved on: 12 February 2017.

[29]. Sarawak Energy. Murum Dam: Fast Facts. https://www.stop-corruptiondams.org/resources/Murum_QA_October.2012.pdf

[30]. Suhakam. 2009. Suhakam's Report on the Murum Hydroelectric Project and its Impact towards the Economic, Social and Cultural Rights of the Affected Indigenous Peoples in Sarawak. http://www.suhakam.org.my/wp-content/uploads/2013/12/Murum1.pdf

[31]. Suruhanjaya Hak Asasi Manusia Malaysia (SUHAKAM). 2011. Laporan Status Hak Pendidikan Kanak-Kanak Orang Asli. Kuala Lumpur: SUHAKAM.

[32]. The Academy of Orton-Gillingham Practitioners and Educators. Undated. The Orton-Gillingham Approach. http://www.ortonacademy.org/approach.php. Retrieved on: 15 February 2017.

[33]. The Conversation. 2018. Explainer: what is phonics and why is it important? $\mathrm{http}$ //theconversation.com/explainer-what-is-phonics-and-why-is-it-important-70522. Retrieved on: 30 July 2018.

[34]. Tvedt, Terje \& Jakobsson, Eva (eds.). 2006. A History of Water: Volume I: Water Control and River Biographies. London: I.B. Tauris. https://books.google.com.my/books?id=3KzP916p6QC\&pg $=$ PA286\&lpg $=$ PA286\&dq $=$ orang + asli + and + langat + basin\&source $=$ bl\&ots $=$ WAfIO5g8vt $\&$ sig $=E C d d w v p Z 9 q \_$mkiWSlsRNlM0HHXw\&hl=en\&sa $=X \&$ redir_esc $=y \# v=$ onepage $\& q=$ orang $\%$ 20asli\%20and\%20langat\%20basin\&f=false. Retrieved on: 12 February 2017. 
[35]. UNESCO. 2000. The Dakar Framework for Action, Education for All: Meeting our Collective Commitments. http://unesdoc.unesco.org/images/0012/001211/121147e.pdf. Retrieved on: 20 February 2017.

[36]. UNESCO. 2014. The Right to Education: Law and Policy Review Guidelines. http://unesdoc.unesco.org/images/0022/002284/228491e.pdf. Retrieved on: 19 February 2017.

[37]. UNESCO. $2016 . \quad$ Education for All $\mathrm{http}: / /$ www.unesco.org/new/en/education/themes/leading-the-international-agenda/education-forall/efa-goals/. Retrieved on: 12 February 2017.

[38]. UNESCO. 2017. Education for All. http://www.unesco.org/new/en/education/themes/leading-theinternational-agenda/education-for-all/

[39]. United Nations. 2008. Declaration on the Rights of Indigenous Peoples. http://www.un.org/esa/socdev/unpfii/documents/DRIPS_en.pdf

[40]. United 2015.2 Nations. 20 Sustainable https://sustainabledevelopment.un.org/?menu=1300. Retrieved on: 12 February 2017.

[41]. United Nations. 2017. The Sustainable Development Agenda. https://www.un.org/sustainabledevelopment/development-agenda/

\section{Biodata of Authors}

Ong Puay Liu, Ph.D., Professor (Anthropology of Development) and Principal Fellow, Institute of Ethnic Studies (KITA), UKM. Research interests include community development, ethnic relations, tourism matters, education for social inclusion.

Ong Puay Tee, Ph.D., Senior Lecturer, Faculty of Business, Multimedia University Melaka. Research interests include management and leadership studies.

Ong Puay Hoon, Ph.D., President of Dyslexia Association of Sarawak, Kuching, Sarawak

Ng Kum Loy, MA, Dyslexia Association of Sarawak, Kuching, Sarawak 